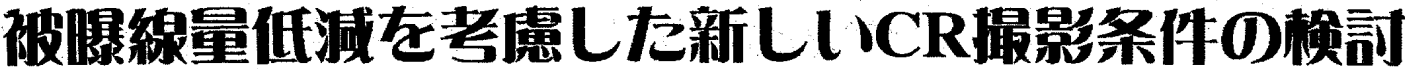

\section{Effectiveness of New CR Parameters in Reduction of Radiation Dose}

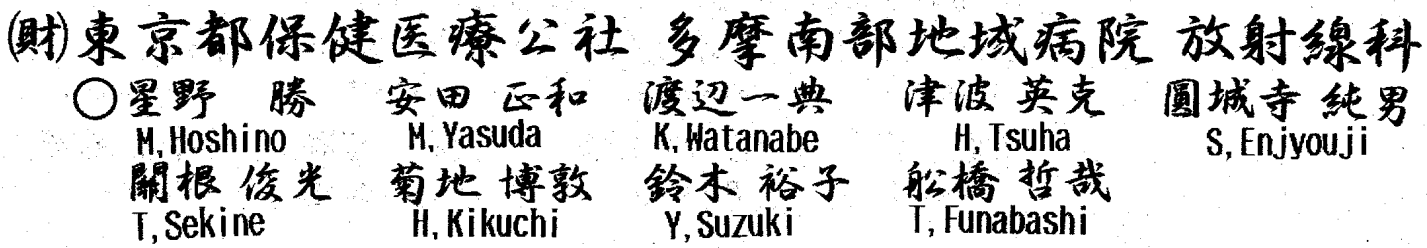

（はじめに）

1980年代に登場したCRの最大の特幑は、film-screen（F S ）法に比へ被 懪線量の大幅な低減が可能である。しかしながら今日、それが達成されている 亡は思われない。被曝低減に貢献する理想的なX線は、低エネルギー成分を 除去した高圧X線が有效と考える。しかし組樴間コントラストを著しく悪くす る要因ともなり、F S システムをべースに構成されているC R システムのAUTO モードでは、診断不能に近い画像となる.

(目的)

低エネルギー成分を除去し極めて硬化された線質により撮影された組辒間コ ントラストの少ない画像情報を、CRの収録処理によりどのように診断可能な 画像にできるかその原理と実験結果を報告する。

(使用機器)

TOSHIBA KXO-80F X線管（固有及び付加ろ過3.4mmAL）

FCR 9000

表1

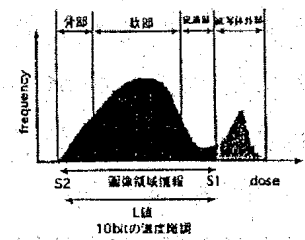

（原理）

IPに記録された被写体を通過したX線の強度分布は、撮影に使用するX線 の低エネルギー成分が少ないものほど、その最大最小值 $\left(S_{\text {max }} S_{\text {min }}\right)$ の幅 は狭くなる。F C RではそのAUTOE一ドにおいてF S 法の撮影条件を基礎しし て常識的な $S_{m a x} S_{m i n}$ を決定しているため、極端に狭い $S_{m a x}: S_{m i n}$ では、 L 值幅の下限リミッッターにより十分な濃度階調（10bit）が行われない。それ を $S_{\mathrm{max}} S_{\mathrm{min}}$ 幅 $\log 0.5$ を限界值として適正し值で収録処理を行うことによ り、軟〜硬 $X$ 線において各濃度分解能 (10bi t ) 同一に表現出来る。

表 1 は一般的な撮影条件で撮影された代表的なヒストグラムを示す。

表 2 は高圧撮影により組樴間コントラストの少ない画像情報は非常に狭い

ヒストグラムとなる。

L 值の適正化により狭い $S_{\mathrm{max}} \mathrm{S}_{\mathrm{m} \text { i n }}$ のわずかな濃度差を10bit 1024階調す る事ができる。

表 3 は、ヒストグラムを濃度差に置換えたものである。低圧撮影時には濃度 差が広いのに対し、高圧撮影では狭い範囲となる。

(実験方法)

1、X線管電圧50kVおよび $140 \mathrm{kV}+1 \mathrm{mmAL}$ でアルミステップを撮影

2、50kVをAUTO $140 \mathrm{kV}+1 \mathrm{mmAL}$ をL值 0.5でそれぞれ収録処理を行う。

3、アルミステップよほぼ同等の厚さである手を撮影し臨床での応用の可能 性を確認する。

写真 $1 \quad a, b$ はこの濃度差をAUTOモードで収録処理 低压撮影では1024階調 されるが、高圧撮影では十分な濃度階調がおこなはれない.しかし適正なし値 で階調すると、アルミステップは十分階調されている（写真1-c）。

写真 2 それぞれの条件で撮影された手である。写真 3 は同様の条件下だが $140 \mathrm{kv}$ の写真を L 值で0, 5 で収録処理すると、50kvと同等のコントラスト得た 写真になる。

(結果)

低エネルギー成分を除去した高压 X線でも適正 し值による収録処理により組 表2

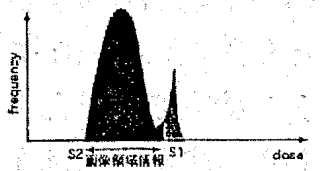

S1:Smax

S2:Smin

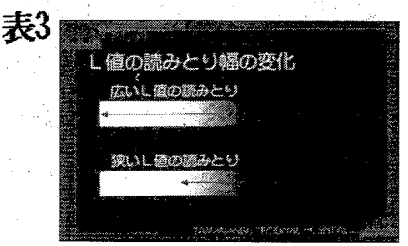

宣真1

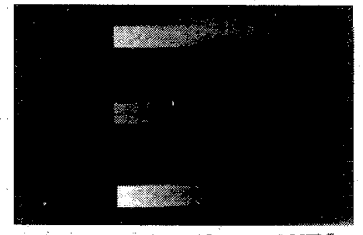

a 上: $50 \mathrm{kV}$ AUT0

b 中: $140 \mathrm{kv}$ AUT0

C下:140kv L值0, 5

写真2

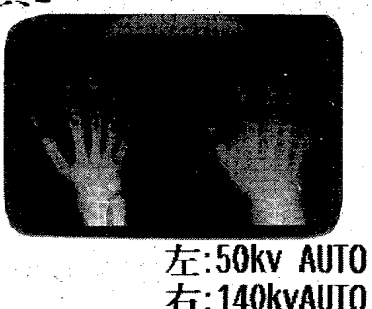

辀間コントラストを同一にすることが可能てあった。

(考察)

この原理によりC Rの撮影条件を硬線質に移行していくことにより大幅な被 港線量低減を実現させる可能性があると考えられる。今後臨床写真に適応して いくためには、線質を同一にした場合、各部位での $S_{m a x} S_{m i n}$ を測定し適 正L値を求めていく、あるいは狭いL 值で固定し、各部位で線質を変化させて いく方法とが考えられる。現在のところ後者では、X線発生器の性能上、極端 な高電珐、少ないmAs 值設定が不可能なため十分な実験は出来ない。

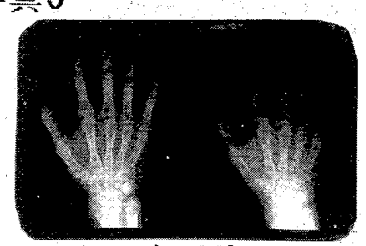

左: $50 \mathrm{kV}$ AUT0 右:140kv L值 0,5 